り高温では309が最もすくれている。しかし C $1001 \%$ 程度では逆に $\mathrm{Ni}$ の低いほじ高温の捻回值が步つてい る.

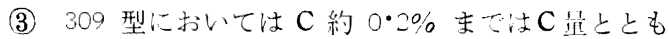

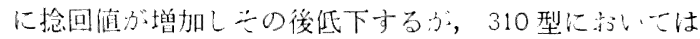

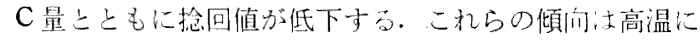
なるほよ゙いちじるしい。またCが低いものは最高捻回値 在示与温度が高い。

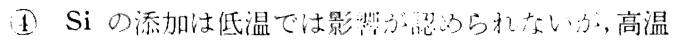
て注各鋼種とも捻回值龙低下寸る.

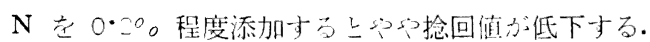

$\mathrm{Ni}$ の增加注二相組織の場合注捻回值を改善させるが, 完全オーステナイトで:士1, $000 \mathrm{C}$ 前後の变形能在低下さ せる傾向ふ諗められる。

$\mathrm{Cr}$ は $1,200 \mathrm{C}$ 前後の捻回值を低下させる.

$\mathrm{Nb}$ は高温の捻回值を急成させる. また Nbの添加に より最高捻回值を示与温度が低温にずれる。

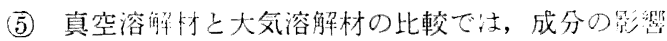
が強く現われ，決定的な差異核認められ琼い。

A1 の添加沙量では揄问值を向上させるが，多量で
はかえつて低下させ，またB捻回值を向上させず，か えつて 0.01\% 添加でも高温側の捻回值が急減する.

B) 熱処理温度を高わ, 結晶粒度を大きくさせても低 C 鋼では捻回檤曲線に変化が認められないが，高 $\mathrm{C}$ 鋼で は粒界のC固溶量の增加の結状, 低温側でも粒界破壊と なるため, 变形能が低下寸ることが知られる.この結果 絬晶粒度てのものは捻回值に影響しないことが結論され る.

(昭和 36 年 4 月寄稿)

\section{交献}

1) F. Bloom, W. Clark Jr, P. Jennings: Metal Progress, 9 (1951), Feb. 250

2）森島：鉄と鋼，44 (1958), 660

3 ) R. Perkins, W. Binder: J. Metals, 9 (1957) 239

4 ) C. Post, D. Schoffstall, H. Beaver: J. Metals, 3 (1951), 973

5 ) D. Laveless, F. Bloom: Iron Age, 179 (1957) June, 20. 95

6 ）加藤, 金井, 阿部: 鉄と錭, 46 (1959) 10, 1268

7 ) C. C CARK, J. Russ: Metals Technology, 12 (1945), Dec, 1839

8 ) 森島：鉄と鋼，42（1956）9,928

\title{
$30 \mathrm{Ni}-20 \mathrm{Cr}$ 系ステンレス鋼の機械的性質と耐食性におよぼす
}

\section{$\mathrm{Mo}, \mathrm{Si}, \mathrm{Cu}$ 単独添加の影響*}

$(30 \mathrm{Ni}-20 \mathrm{Cr}$ 系ステンレス鋼に関する研究一I $)$

\author{
井上繁弘** \\ Effect of Mo, Si and $\mathrm{Cu}$ Additions, Respectively, on Mechanical \\ Properties and Corrosion Resistance of 30Ni-20Cr Stainless Steel.
}

(Studies on $30 \mathrm{Ni}-20 \mathrm{Cr}$ stainless steels-I)

Synopsis:

Shigehiro INOUE

Changes of mechanical properties and corrosion loss were observed with specimens of $\mathrm{Ni}-\mathrm{Cr}$ stainless steels by varying $\mathrm{Mo}$, Si and $\mathrm{Cu}$ contents, respectively.

The following results were obtained:

(1) The higher the Mo content, the higher the tensile strength, the yield strength and che elastic limit of forged specimens. But the maximum tensile strength of cast specimens was obtained by addition of $8.8 \%$ Mo.

(2) The minimum corrosion loss in a boiling solution of 5 wt. $\% \mathrm{H}_{2} \mathrm{SO}_{4}$ and $\mathrm{HCl}$ was obtained by addition of $3 \sim 4 \%$ Mo, also the minimum grain-boundary corrosion loss was obtained by addition of $3 \sim 7 \%$ Mo.

(3) Effect of $\mathrm{Si}$ and $\mathrm{Cu}$ contents on mechanical properties and corrosion loss was less than that of Mo.

** 昭和 36 年 4 月本会講演大会にて発表 ** 太平金属工業株式会社 


\section{I. 緒}

言

一般に 20 合金と称之れる耐食性高 $\mathrm{Ni}$ オーステナイ トステンレス鋼は約 $30 \% \mathrm{Ni}, 20 \% \mathrm{Cr}$ に Mo, Cuお よび Siをこ〜 4\% 程度含有した公金一, Durimet 20, Carpenter 20, Alloy Co 20, Elcomet および Worthite などの商品名こ卧肌，18-8采ステンレス銅の耐 食性，特に酎硫酸性空改良したものである。

最近わが国における石油化学，合成化学などの急速な 発展によりこれら工業に使用される硫酸の淽度, 温度の 条件ぶ苛酷になつたためその構造材料としここれらの合 金の使用が活発になつたが，なおより優れた性質をも要 求されるように机つてきた.

しふしながらこれらの合金に関する研究は各製造会社 の資料以外に見るべきものぶ少ないので本実娩さは，30 $\mathrm{Ni}-20 \mathrm{Cr}$ を基とし， Mo, Si および $\mathrm{Cu}$ をそれでれ単 独に添加して, 添加元素の種類および量による機械的性 質と酎食性におよぼす影響を鍛造材，鋳物について調心゙ i.

\section{II. 試料ならびに実験方法}

試料は $100 \mathrm{~kg}$ ，高周波誘導電気炉で熔製し，鋳物法 ASTM-B-100 の引張試験片採取用鋳塊江鋳込口, ま た鉔造材は $50 \square \times 300$ に鋳造してから $28 \oint \times \mathrm{L}$ :鍛造
した.

試料の化学成分を Table 1 示吉. 引張試験江は JIS 4 号試験片を用い, 耐力, $(0.2 \%)$ 弾性限, $(0.02$ \%) 堂求々るための精密伸び测定には extensometer

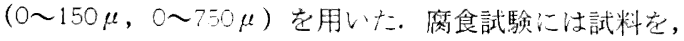
$20 \mathrm{~mm}$ \& $\times 6 \mathrm{~mm}$ に旋削し, エメリーで 500 番まて研 摩して, $5 \% \mathrm{HCl}$ 沸騰中で $24 \mathrm{~h}, 5 \% \mathrm{H}_{2} \mathrm{SO}_{4}$ 沸騰中で $6 \mathrm{~h}$, 扩よび $65 \% \mathrm{HNO}_{3}$ 沸騰中で $48 \mathrm{~h} 3$ 回浸漬し,

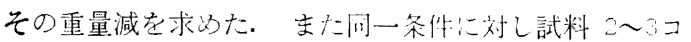
使用し，その平均を測定值とした。

\section{III. 実 験 結 果}

1. 溶体化温度の影響

鋳物試料 S117を1,000 C から 1,250 C Cで $50^{\circ} \mathrm{C}$ おきに $1 \mathrm{~h}$ 加熱保持し水泠して機械的性質を测定した。

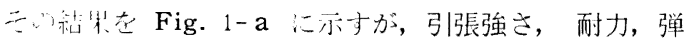
性限は1１１０Ｃ文で徐々に低下するがそれ以上ではあ文 り変化がない，伸びは温度が上昇するにつれて大きくな り，硬度はいちじるしく軟化する。このことは Fig. 2 にしいちように，オーステナイト組織のほかに interdendritic に現われている相が溶体化温度の上昇につれ て，急激に少なくなることによるものと思われる．

つぎ鋳物試料 S 217 について前述と同様に試験し

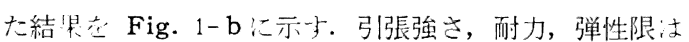

Table 1. Chemical compositions. (\%)

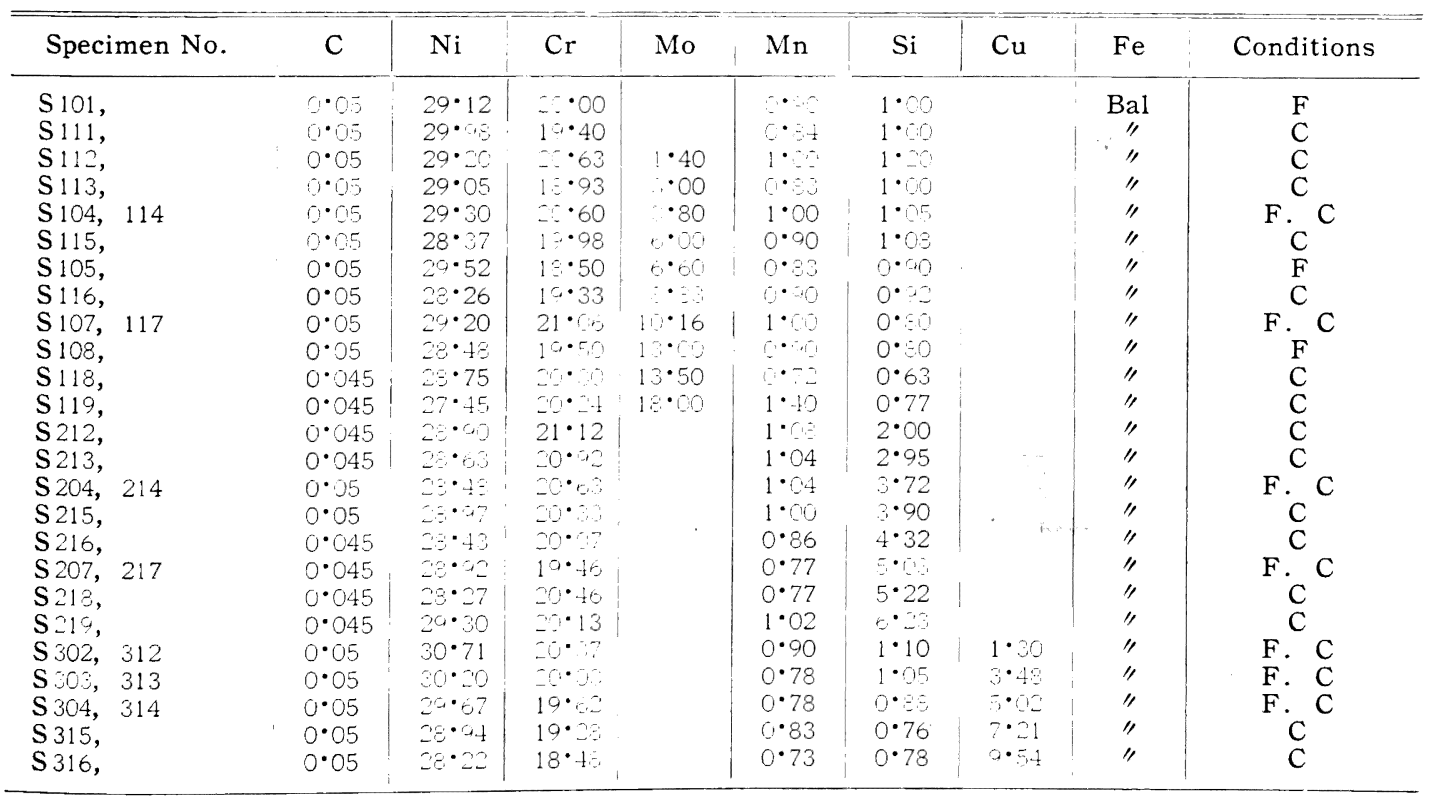

$\mathrm{F}=$ Forged specimens,$\quad \mathrm{C}=$ Cast specimens 


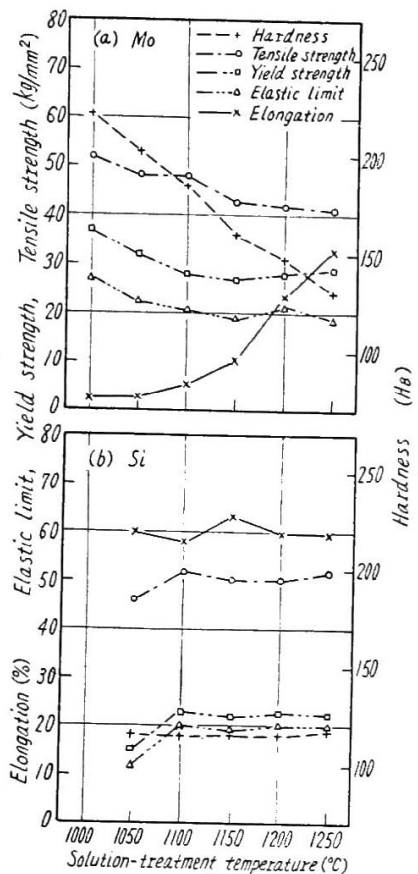

Fig. 1. Relation between mechanical properties and solution-treatment temperature with $30 \mathrm{Ni}-20 \mathrm{Cr}$ stainless steel containing 10\% Mo (a) and $5 \% \mathrm{Si} \mathrm{(b).}$ $1,100^{\circ} \mathrm{C}$ で上昇

し，それ以上の

温度ではあまり

変化しない.ま た伸び，硬度は ほとんど一定で ある.この場合 顕微鏡組織はい ずれもオーステ ナイト組織のみ である。

2. 機械的性 質におよぼす Mo の影響

Mo を添加し た鍛造材試料 101, S 104, S 105, S107, S 108 について $1,100^{\circ} \mathrm{C} \times 1 \mathrm{~h} \rightarrow$ 水冷の溶体化処 理它行なつて, 引張試験, 硬度 および衝整值を

测定した結果を Fig. 3-aに示す. 引張強さ，耐力，お よび弾性限は Mo 量が増すほどいちじるしく大きくな る. 伸びは Mo 量 6\% まで漸減し，10\%以上では急に 低下する．また衝整值も同様に Mo 量 10\%を超える と急に低下し, 硬度はMo 量が増すほどいちじるしく硬 化する. 鍛造材は Mo 量約4\%までは均一なオーステナ イト組織であるが. Mo 量約 6\% を超えると Fig. 4-a に示すように明らが異相が認められ，Mo 量が多くな ると次第にその量が増加する.
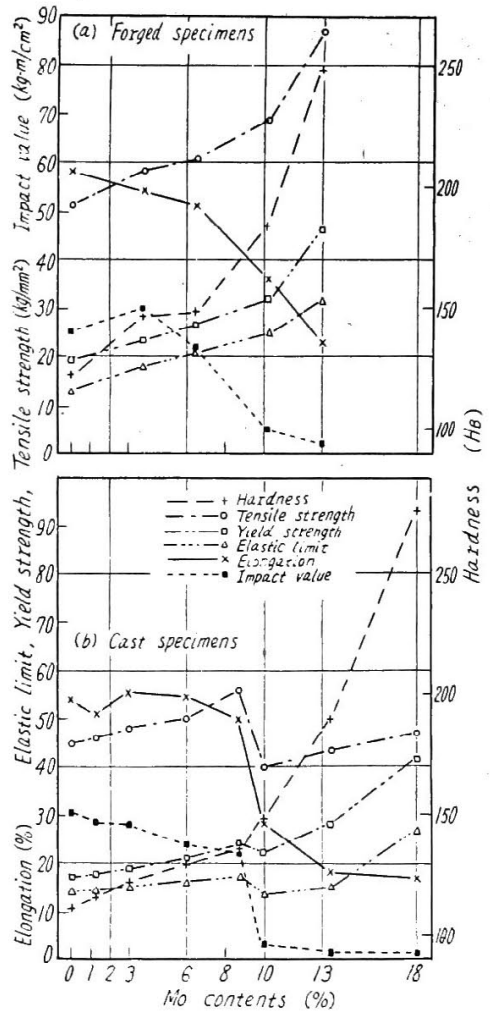

Fig. 3. Effect of Mo contents on mechacial properties of solution-treated $30 \mathrm{Ni}$ $20 \mathrm{Cr}$ stainless steels.

したがつて鍛造材において Mo 量の増加に伴なら伸 び, 衝撃值の低下はその相の発生および増加によるもの である. Mo 量 13\% についてはまだ鍛造が比較的容易 であり, 引張強さ, $87 \mathrm{~kg} / \mathrm{mm}^{2}$, 耐力 $46 \mathrm{~kg} / \mathrm{mm}^{2}$ 弾 性限, $31 \mathrm{~kg} / \mathrm{mm}^{2}$ 伸び, $23 \%$ Нв 250 定示し非常に強 靶な性質を有している.

Mo を添加した鋳物試料 S111，S112, S113， S115, $\mathrm{S} 116, \mathrm{~S} 117, \mathrm{~S} 118, \mathrm{~S} 119$ について $1150^{\circ} \mathrm{C} \times 4 \mathrm{~h} \rightarrow$

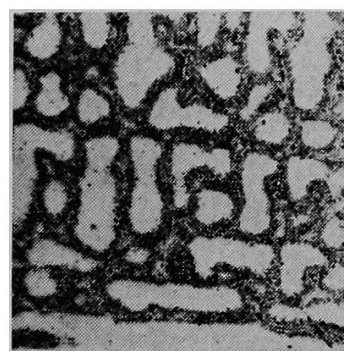

(a) $1,050^{\circ} \mathrm{C} \times 1 \mathrm{~h} \rightarrow \mathrm{W} \cdot \mathrm{Q}$.

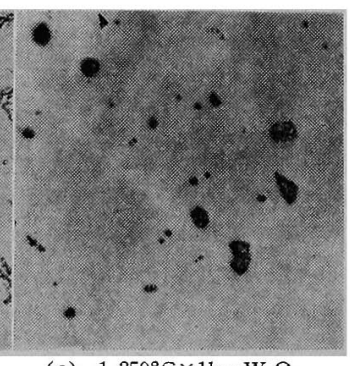

(c) $1,250^{\circ} \mathrm{C} \times 1 \mathrm{~h} \rightarrow W \cdot \mathrm{Q}$.

Fig. 2. Effect of solution-treatment temperature on microstructures of cast $30 \mathrm{Ni}-20 \mathrm{Cr}$ stainless steel containing $10 \% \mathrm{Mo}$. $\times 150(2 / 3)$

水冷の溶体化処理を行なつて引 張試験, 硬度および衝慗值を測 定した結果を Fig. 3-b に示 す. 引張強さは Mo 量が約 $9 \%$ まで增すと $45 \mathrm{~kg} / \mathrm{mm}^{2}$ から $55 \mathrm{~kg} / \mathrm{mm}^{2}$ まで増大して最大 值を示すが，Mo 量が 10\%に なるとかえつて急激に低下し， それ以上 Mo 量が増加しても漸 増する程度である. 耐力, 弾性 限は Mo 量約 $9 \%$ まで漸増し， 


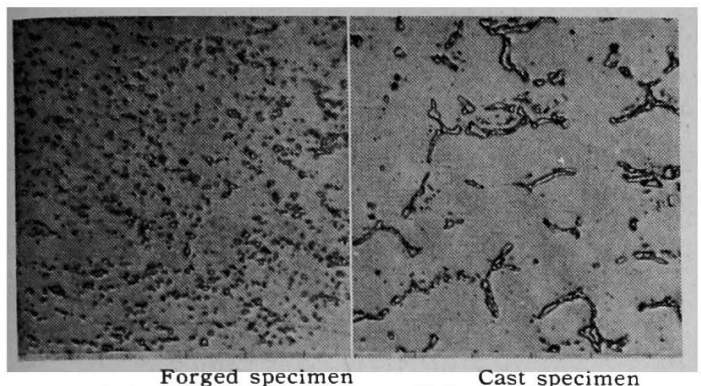

$\begin{array}{ll}\text { (a) } 1,100^{\circ} \mathrm{C} \times 1 \mathrm{~h} \rightarrow W . \mathrm{Q} & \text { (b) } 1,150^{\circ} \mathrm{C} \times 4 \mathrm{~h} \rightarrow W . Q\end{array}$

Fig. 4. Microstructures of forged and cast $30 \mathrm{Ni}-20 \mathrm{Cr}$ stainless steel containing 10\%

Mo. $\times 150(2 / 3)$

10\% でやや低下するが約 13\% からいちじるしく大き くなる．伸び，衝揧値は Mo 量 10\% から急に低下寸 る. 硬度は Mo 量が増すほど高く, Mo 量 $10 \%$ 以上 ではいちじるしく增加する。

鋳物も Mo 約 4\% なでは均一なオーステナイト組織 である. Mo 約 6\% を超えると Fig. 4-b に示す上う に異相が認められるが，Mo 量が増加してそれが連なる ようになると鍛造材よりも伸さ，衝揧値がいちじるしく
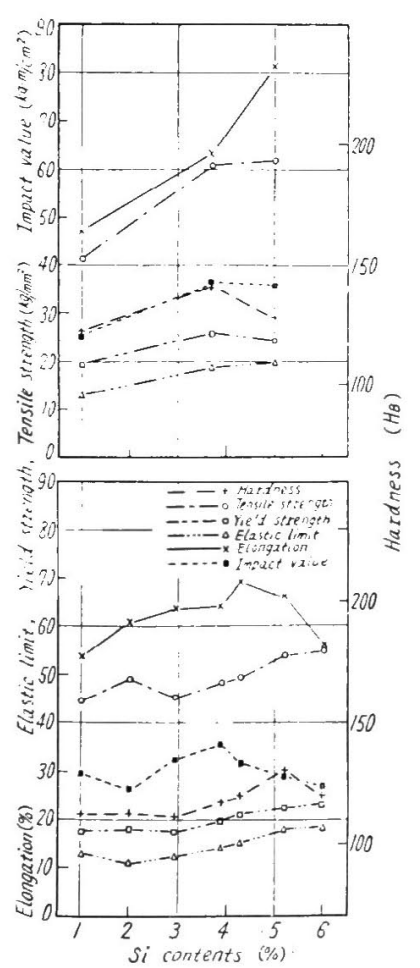

Fig. 5. Effect of $\mathrm{Si}$ content on mechanical properties of solution-treated $30 \mathrm{Ni}-20 \mathrm{Cr}$ stainless steels.
低下してまつたく脆 化し，それに伴つて 引張強さ, 耐力, 弾 性限も一時的に低下 する.

3. 機械的性質 およぼす Si の影響 鋭造材試料 S 204 , S207 について 1100 $\mathrm{C} \times 1 \mathrm{~h} \rightarrow$ 水汾の溶 体化処理をして, 前 回と同様な試験を行 い,その結果をFig. 5-aに示す. $\mathrm{Si}$ 量 3・7\% で引張強亡, 耐力, 弾性限は心な り大きくなるふ，Si 量か 5\%:增加し てもそれほど強くな らない. 伸びは Si 量 $5.0 \%$ で急激に増 加するふ, 硬度はむ しろ低下する。

鋳物試料 S212, S 213, S215, S 216
について $1,150 \mathrm{C} \times 4 \mathrm{~h} \rightarrow$ 水冷の溶体化処理をして, 前 回同様の試験孛行い, その結果花Fig. 5-b に示す. 引張 強さは $\mathrm{Si}$ 量 $2.0 \%$ で $50 \mathrm{~kg} / \mathrm{mm}^{2}$ を示声方，4\% か ら增大して $6 \%$ では $55 \mathrm{~kg} / \mathrm{mm}^{2}$ となり, Mo を添加 した鋳物の最大值と同じ值を示寸. 耐力, 弾性限は $\mathrm{Si}$ 量 $3 \%$ を超えると溸增する. 伸びは $\mathrm{Si}$ 量 $4 \cdot 3 \%$ で最 大值 $70 \%$ を示し, 硬度は $5 \cdot 2 \%$ で最高值を示し, 衝 揧值は $+\cdot 3 \%$ 以上で低下し始める.

Siを添加した試料の顕微鏡組織は Si 量の多少によ らず均一なオーステナイト組織である.したがつて Si が固溶することによつてオーステナイト相の強度が変化 している上考えられるが，Mo 添加の場合のように異相 が存在しないので溶体化処理後の機械的性質におよぼす $\mathrm{Si}$ 量の影響は Moに比べて小さいことがわかる.

\section{4. 機械的性質におよぼす $\mathrm{Cu}$ の影響}

鉎造材試料 S $302, \mathrm{~S} 303, \mathrm{~S} 304$ について $1,100^{\circ} \mathrm{C} \times$ $1 \mathrm{~h} \rightarrow$ 水泠の溶体化処理をし七, 前回同様の試験を行い, その結果を Fig. 6-aに示す. 引張強さ, 耐力, 弾性限 抢よび硬度はゃや大きくなる傾向が見られる程度でほと んど影響がない. 伸さ，衝整值もやや低下の傾向が見ら れる程度であまり影響がない。

鋳物試料 S 312, S 313, S 314, S 315, S 316 につw

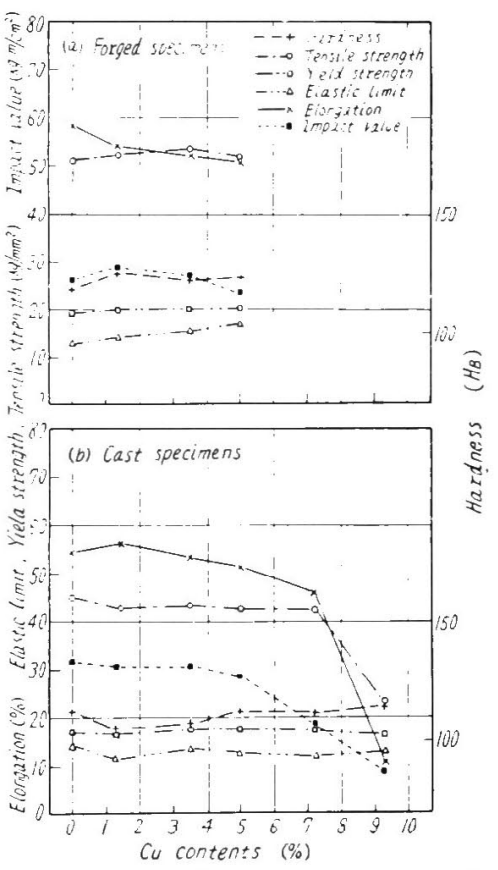

Fig. 6. Effect of $\mathrm{Cu}$ content on mechanical properties of solution-treated $30 \mathrm{Ni}$ $20 \mathrm{Cr}$ stainless steels. 


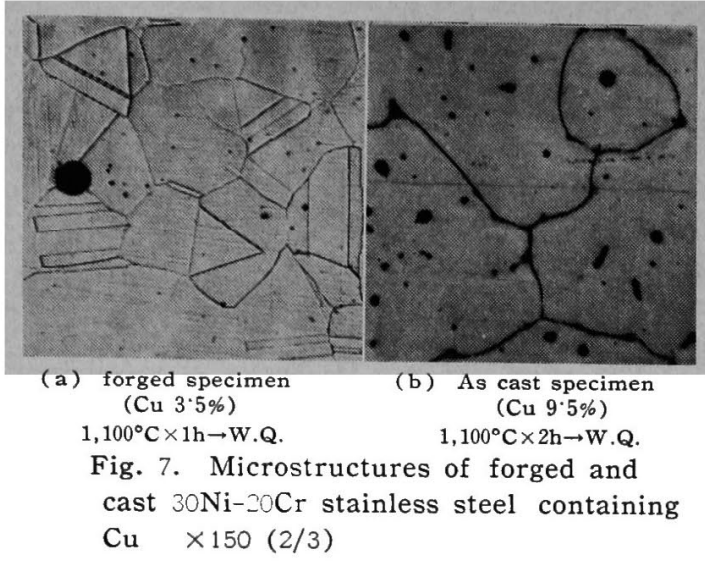

$\tau 1,100^{\circ} \mathrm{C} \times 2 \mathrm{~h} \rightarrow$ 水冷の溶体化 処理をして, 前回同様 の試験を行い, その結果を Fig. 6-bに示す. 引張強さ は Cu 量7\% までほとえど変らないが，それ以上にな ると急に低下与る. 耐力, 弾性限は $\mathrm{Cu}$ 量 $9.5 \%$ まで変 化がない，伸びは徐々に低下し $\mathrm{Cu}$ 量 9.5\% では急激 に低くなり, 衝撃値は $\mathrm{Cu}$ 量 7\% から低下し始める.

$\mathrm{Cu}$ を添加すると Fig. 7- a に示すように黒銅色の球状 介在物が認められ， Cu 量が増加するにつれて多くなる.

鋳物の場合には，これが結晶粒内の最終凝固部分に存 在し， $\mathrm{Cu}$ 量が増加すると粒界にも現われ，Fig. 7-b に示すように $9.5 \%$ になると全粒界を覆うようになる。 したがつて $\mathrm{Cu}$ 量を增加しても固溶することが少なく析 出する傾向があるのでオーステナイト相の強度にはほ上 んど影響を与えないばかりでなく，伸びを減少させるよ うである.特に鋳物のように粒界が全部 $\mathrm{Cu} て ゙$ 覆れると 伸び，衝慗值，引張強さが急激に低下寸る．したがつて $\mathrm{Cu}$ の影響は多量になるとむしろ機械的性質を低下させ る.

5・耐食性におよぼす $\mathrm{Mo}, \mathrm{Si}, \mathrm{Cu}$ の影響

\section{a. 硫酸に対する影響}

酸硫に対する $\mathrm{Mo}, \mathrm{Si}, \mathrm{Cu}$ の影響を調べるために各元 素を添加した鍛造材試料を $1,100^{\circ} \mathrm{C} \times 1 \mathrm{~h} \rightarrow$ 水冷した後 にJISによるステンレス鋼の腐食試験，すなわち $5 \%$ 沸騰硫酸中で $6 \mathrm{~h}$ の腐食試験を行い, その結果を Fig. 8 に示す. Mo の影響については， $4 \%$ で最小值を示し それ以上 Mo 量が増加しても耐食性は改良されないが, Mo 量 13\% では最小值に近い值を示している. Si お よび $\mathrm{Cu}$ の影響についてはいずれも腐食量は減少せずか えつて增加する傾向がある.

\section{b. 塩酸に対する影響}

塩酸に対する $\mathrm{Mo}, \mathrm{Si}, \mathrm{Cu}$ の影響を調べるために各 元素を添加した鍛造材および鋳物試料をそれぞれ 1,100
${ }^{\circ} \mathrm{C} \times 1 \mathrm{~h} \rightarrow$ 水冷, $1,150^{\circ} \mathrm{C} \times 4 \mathrm{~h} \rightarrow$ 水 冷した後に，5\% 沸 騰塩酸中で $24 \mathrm{~h}$ の 腐食試験を行い，そ の結果を Fig. 9 に 示す.

Mo の影響につい て鍛造材試料は Mo 量 $4 \%$ で急激に腐 食量が少なくなり, Mo 量 6.6\%で最小 值を示すが，Mo 量 10\%ではかえつて增 加し 13\% で再び最

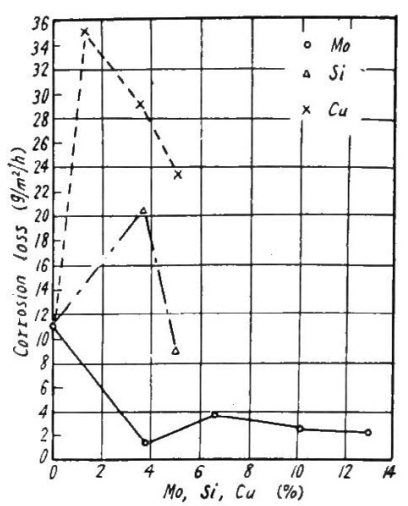

Fig. 8. Effect of $\mathrm{Mo}, \mathrm{Si}$, and $\mathrm{Cu}$ contents on corrosion loss of $30 \mathrm{Ni}-20 \mathrm{Cr}$ stainless steel in boiling solution of $5 \mathrm{wt}$. \% $\mathrm{H}_{2} \mathrm{SO}_{4}$. 小值に近くなる．鋳

物では Mo 量 3\% で最小值を示し, それ以上ではやや 増加し，18\% で再び減少する. すなわち Mo 量 3〜4 \%ではほほ最小值を示し，それ以上Mo を増加しても耐 食性はよくならない. Si の影響については, Si が增す につれて腐食量は滅少するが，Mo 添加の試料に比べて かなり大きい。

$\mathrm{Cu}$ の影響については, $\mathrm{Cu}$ 量 1\% で腐食量はいちじ るしく低下するが，それ以上 $\mathrm{Cu}$ を増加してもわずかに 低下する程度であまり影響がない，またその腐食量は Mo 添加の試料の最小值よりやや大きい.

\section{c. 粒界腐食に対する影響}

粒界腐食におよぼす $\mathrm{Mo}, \mathrm{Si}, \mathrm{Cu}$ の影響を調べるため に各鍛造材を $1,100^{\circ} \mathrm{C} \times 1 \mathrm{~h} \rightarrow$ 水冷の溶体化処理後, 650 ${ }^{\circ} \mathrm{C} \times 2 \mathrm{~h} \rightarrow$ 空冷で sensitize したものについて Huey Test（硝酸 65\% 沸騰 $48 \mathrm{~h} ， 3$ 周期）を行い，その結

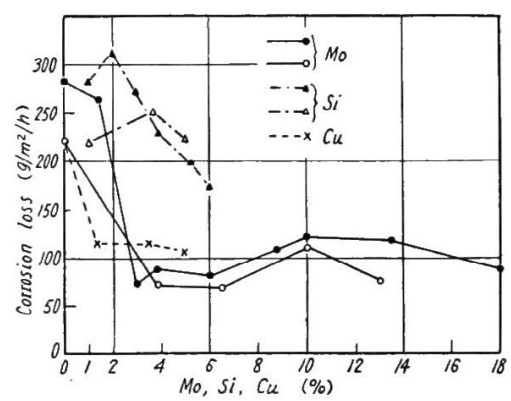

Fig. 9. Effect of $\mathrm{Mo}, \mathrm{Si}$ and $\mathrm{Cu}$ contents on corrosion loss of $30 \mathrm{Ni}-20 \mathrm{Cr}$ stainless steel in boiling solution of $5 \mathrm{wt}$. \% $\mathrm{HCl}$. 


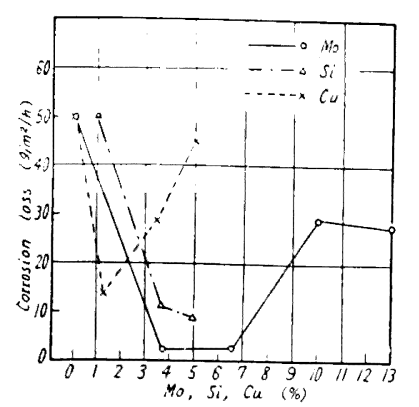

Fig. 10. Effect of Mo, Si and $\mathrm{Cu}$ contents on corrosion loss of $30 \mathrm{Ni}-20 \mathrm{Cr}$ stainless steel in boiling solution of $65 \%$ $\mathrm{HNO}_{3}$.

果を Fig. 10 に示 于.

Mo の影響につい 二は 4\% から 7\% の間で腐食量は少な く, 10\%以上で再び 増加する. Si の影 響については, Si 量 が増加するほど腐食 量は少なくなるふ， Mo 量 $4 \sim 7 \%$ の場 合よりも多い. $\mathrm{Cu}$ の影響については $\mathrm{Cu}$ 量 $1 \%$ で少なくなるが，それ以上では $\mathrm{Cu}$ 量が増 加するほど腐食量も増加する。

\section{IV. 結言}

以上の諸結果を要約するとつぎの通りである.

（1）溶体化温度が機械的性質におよぼす影響につい ては, Mo 量 10\% の鋳物では温度が高くなるにつれて 硬度がいちじるしく低下し, 伸びは大きくなるが, 引張 強さ, 耐力, 弾性限は $1,150^{\circ} \mathrm{C}$ まて漸減し, それ以上の 変化は認められない. Si 量 $5 \%$ の鋳物は $1,100^{\circ} \mathrm{C}$ 以上 でばとんど変化がない。
（2）㙨械的性質におよぼすMoの影響について泣，

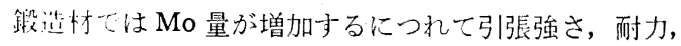
弾性限および硬度は，次第に向上し，とくにMo を13\% 含えだものはまだ鍛造加工も十分可能で，これらの性質 がいちじるしく大きくなる、また鋳物では引張強さは Mo 量 8・00\%で最大となり，てれ以上ではかえつて低 下ナるが硬度はさらにいちじるしく高くなる.

（3） Si の影響については，Mo汪ど顕著な影響はな いが，鍛造材，鋳物のいずれも $\mathrm{Si} ： 4 〜 5 \%$ て引張強さ， 耐力, 弾性限および伸びを向上するのに役立つている. また $\mathrm{Cu}$ の影響については50\%まで始えど変化がなく， それ以上になるとかえつて維械的性質はかなり低下寸 3.

（4）腐食量に対するMoの影響については, 溶体化 処理のもので， 5\% 沸騰硫酸，5\% 沸騰塩酸中で汢Mo: 3〜4\% で最小值を示し, それ以上 Mo を增しても改良 されずやや増加の傾向を示す。また粒界腐食試験(Huey Test）では. 650 C てで焼鈍したもの注 Mo：3〜7\% で かなり減少する。

（5）腐食量に対する $\mathrm{Si}$ および $\mathrm{Cu}$ 添加の影響は $\mathrm{Si}$ : 約 5\%で粒界腐食をやや減少せしめ $\mathrm{Cu}: 1 \%$ で耐 塩酸性を若干改良する程度であまり効果はない。

(昭和 36 年 5 月寄稿)

\title{
$\gamma$ 型 Fe-Co-Cr-Ni 基耐熱合金, LCN-155の時効析出相の
}

\section{化学組成および時効による各元素の挙動について*}

\section{( $\gamma$ 型耐熱合金の焼戻過程に関する研究一IV)}

\author{
今井勇之進 ${ }^{* *} \cdot$ 増本 健**
}

On Chemical Composition of Secondary Phases and Behavior of Each

Element by Aging in the Gamma-Type $\mathrm{Fe}-\mathrm{Co}-\mathrm{Cr}-\mathrm{Ni}$ Base

Heat-Resisting Alloy, LCN-155.

(Study on tempering process of $\gamma$-type heat-resisting alloys.-IV)

Yünoshin IMAI and Tsuyoshi Masumoto

Synopsis:

In the present study, the chemical compositions of secondary phases and the behavior of each element by aging after solution-treatment with the LCN-155 type heat-resisting alloys were examined by chemical analyses of residues extracted electrolytically.

* 昭和 33 年 4 月本会講演大会にて発表 ** 東北大学金属材料研究所, 工博 